\title{
ABBREVIATION OF BERSON TECHNIC FOR ESTIMATION OF THYROIDAL CLEARANCE OF PLASMA RADIOIODIDE: USE OF BERSON TEST TO RECOGNIZE THYROIDAL PROTEIN-BINDING DEFECTS
}

\author{
By CHARLES A. OWEN, Jr., RALPH S. McCANTS * and WILlIAM M. McCONAHEY \\ (From the Mayo Clinic and Mayo Foundation, $\dagger$ Rochester, Minn.)
}

(Submitted for publication September 15, 1959; accepted January 29, 1960)

Berson, Yalow, Sorrentino and Roswit (1) designed a simplified technic for estimating the rate at which the thyroid gland clears the plasma of intravenously administered radioiodide $\left(\mathrm{I}^{131}\right)$. The amount of $\mathrm{I}^{131}$ taken up by the thyroid in 30 minutes is correlated with the average concentration of $\mathrm{I}^{131}$ in the plasma during the half hour. Plasma $\mathrm{I}^{131}$ is not actually measured, but is determined on the assumption that its concentration is a function of the weight of the body. Regardless of this and other assumptions involved, the method is one of the most precise in evaluation of thyroidal function in our experience $(2,3)$.

Calculation of clearances at periods of time less than 30 minutes has been found necessary on those infrequent occasions when there was an electronic or mechanical failure of the radiation detector, or when the patient was so restless that the uptake tracing became erratic before the 30 minute time was concluded.

In an attempt to determine whether the Berson procedure might be shortened, 1,250 of our records were reviewed. One hundred particularly uniform tracings, with clearance values of not less than 10 to more than $300 \mathrm{ml}$ of plasma cleared of $\mathrm{I}^{131}$ per minute, were analyzed at various intervals between 5 and 30 minutes to establish new mathematical constants for practical application of the test.

During the course of our review, 11 tracings were found in which an initial uptake of $\mathrm{I}^{131}$ was succeeded, after about 10 or 20 minutes usually, by a reversal of the curve. Not only do these cases present a problem in the calculation of clearance of plasma $\mathrm{I}^{131}$, but their rarity (about 1 per cent) seems to warrant their presentation.

* Fellow in Pathology, Mayo Foundation.

$\dagger$ The Mayo Foundation, Rochester, Minn., is a part of the Graduate School of the University of Minnesota.

\section{METHOD}

The Berson technic (1) was followed closely, with the only modification consisting of adaptation to our in vivo equipment: a 2 inch $(5.1 \mathrm{~cm})$ sodium iodide (thallium-activated) scintillation crystal situated at a distance of $20 \mathrm{~cm}$ between the surface of the crystal and the skin overlying the thyroid. The radioactivity was registered continuously on a counting rate-meter and in turn on an Esterline-Angus recorder (for example, Figure 1). Pulse-height discrimination was so set that 100 counts per second were recorded per microcurie of $\mathrm{I}^{131}$ in the neck.

The equation for calculating the thyroidal clearance ( $\mathrm{Cl}$ in milliliters cleared per minute), based on the observations of Berson and colleagues, is $\mathrm{Cl}=\frac{\mathrm{Th} \cdot 200 \cdot \mathrm{W}}{\overline{\mathrm{D}} \cdot 30}$, where $T h$ is the calculated uptake of $\mathrm{I}^{131}$ during the test, $\mathrm{W}$ is the body weight in kilograms, $\overline{\mathrm{D}}$ is the calculated average fraction of the retained dose of $\mathrm{I}^{131}$, and 30 is the length of test in minutes. Berson's group found a fairly constant ratio between body weight and the fraction of the retained dose of $\mathrm{I}^{131}$ in the plasma, a plasma/ body weight constant expressed by the number 200 in the above equation.

From the 100 tracings under analysis, the uptake (Th) was calculated at $5,7.5,10,15,20$ and 25 minutes; the time in the denominator was changed accordingly. Assuming $\mathrm{Cl}$ from the standard 30 minute test, the only unknown became the plasma/body weight constant; this was then simply calculated.

\section{RESULTS}

Calculation of the plasma radioiodide/body weight constant for various intervals of time between 5 and 30 minutes, instead of the conventional 30 minutes, is presented in Table $I$. The standard deviation is seen to increase as the duration of the test diminishes. However, the error at 20 minutes is sufficiently small that it seems warranted to abbreviate the test routinely to this time from the standpoint of comfort to the patient.

Data on 11 patients with a reversing uptake pat- 
tern are included in Table II, and the actual uptake curves are reproduced in Figure 2.

It is clear from inspection of the curves that the standard Berson procedure is inappropriate for the calculation of thyroidal clearance of plasma $\mathrm{I}^{131}$ in these cases. This may be shown numerically by calculating the "clearance" at 5 minutes as well as at 30 minutes (Table II). In Patient 5 , the one with iodide goiter, "clearances" were found to be $149 \mathrm{ml}$ per minute at 5 minutes, 126 at 10,108 at 15,94 at 20,82 at 25 , and only 74 at 30 minutes. Since the diminishing "clearance" values reflect a loss of $\mathrm{I}^{131}$ from the thyroid during the test, none of these values truly represents the clearance. The closest approximation was reached by extrapolating the values to time zero, which yielded, in this instance, about $170 \mathrm{ml}$ per minute.

\section{DISCUSSION}

The usual pattern of uptake of $I^{131}$ by the thyroid gland is a continuously rising one until secretion of hormonal $\mathrm{I}^{131}$ reverses the curve. In normal persons this usually takes place about a day after the dose of $\mathrm{I}^{131}$ is given; in an occasional

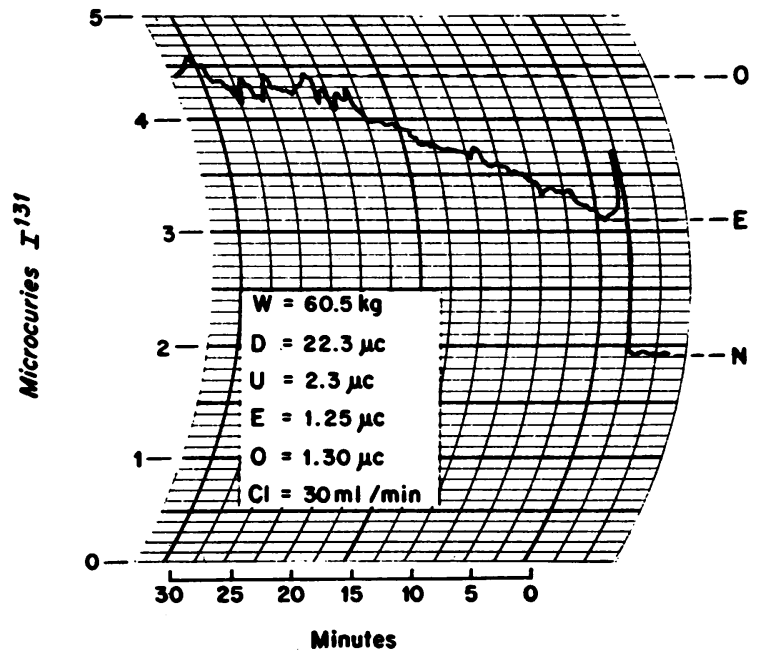

Fig. 1. ERratic ReCORd of thyroidal UPtake of I ${ }^{131}$. The patient was restless the last 15 minutes of the test. $\mathrm{N}$, neck background before test started; $\mathrm{E}$, extrathyroidal $\mathrm{I}^{131}$ in the neck before significant $\mathrm{I}^{131}$ was taken up by thyroid; $\mathrm{O}$, observed uptake of $\mathrm{I}^{: 31}$ during half hour test (actually the difference between value at 30 minutes and value $\mathrm{E}$ ) ; W, weight of patient; $\mathrm{D}$, intravenously administered dose of $\mathrm{NaI}^{131}$; $\mathrm{U}$, urinary excretion of $\mathrm{I}^{131}$ during test; $\mathrm{Cl}$, thyroidal clearance of plasma $\mathrm{I}^{131}$ calculated from these data.
TABLE I

Plasma radioiodide constants $(k)$ in the Berson test of thyroidal clearance of plasma $I^{131}$, at intervals of 5 to 25 minutes after equilibration in the neck of intravenous doses of $I^{131}$

\begin{tabular}{|c|c|c|c|c|}
\hline \multirow{2}{*}{$\begin{array}{l}\text { Minutes } \\
\text { after } \\
\text { equili- } \\
\text { bration }\end{array}$} & \multirow[b]{2}{*}{ k* } & \multicolumn{2}{|c|}{ $\pm 1 \mathrm{SD}$} & \multirow{2}{*}{$\begin{array}{c}\text { k* }^{*} \\
\text { Values } \\
\text { proposed } \\
\text { for } \\
\text { routine } \\
\text { use }\end{array}$} \\
\hline & & & $\begin{array}{l}\text { As \% } \\
\text { of } k\end{array}$ & \\
\hline $\begin{array}{l}25 \\
20 \\
15 \\
10 \\
7.5 \\
5\end{array}$ & $\begin{array}{l}191.1 \\
180.0 \\
168.9 \\
157.2 \\
147.6 \\
137.3\end{array}$ & $\begin{array}{r}6.9 \\
9.6 \\
13.6 \\
18.4 \\
20.3 \\
23.2\end{array}$ & $\begin{array}{r}3.6 \\
5.3 \\
8.1 \\
11.7 \\
13.8 \\
16.9\end{array}$ & $\begin{array}{l}190 \\
180 \\
170 \\
160 \\
150 \\
135\end{array}$ \\
\hline
\end{tabular}

${ }^{*} \mathrm{k}=$ Mean value for the constant of plasma $I^{131} /$ body weight. The mean values for $\mathrm{k}$ are based on 100 studies of uptake. The value for $\mathrm{k}$ at 30 minutes was taken as 200 . Berson and associates experimentally determined that in the 30 minute period of their test the average fraction of a dose of I $^{131}$ retained (that is, not in the thyroid or urine) per milliliter of plasma when multiplied by the body weight in kilograms was $5 \times 10^{-3}$. In the development of the clearance equation, this value, transposed from the denominator to the numerator, becomes $0.2 \times$ $10^{3}$ or 200 .

patient with hyperthyroidism, hormonal secretion may begin to reduce thyroidal $\mathrm{I}^{131}$ as early as two hours after the dose, although the peak uptake in Graves' disease usually occurs several hours later.

In contradistinction to this conventional pattern, 11 patients were observed in whom thyroidal release of $I^{131}$ became evident within the first onehalf hour to one hour; it was recognized only because the Berson clearance test was being performed.

Details on the patient with "iodide goiter" have been reported (4). Paris and associates, studying this patient and other patients with "iodide goiter," found that after a rapid initial uptake of $\mathrm{I}^{131}$ by the goitrous thyroid, there was a reversal of the uptake curve (4). The rate of disappearance of $\mathrm{I}^{131}$ from the thyroid gland exactly matched the rate of disappearance of $\mathrm{I}^{131}$ from the blood stream. Since no hormonal $\mathrm{I}^{131}$ was recoverable, it would appear that these patients had an adequate or exaggerated iodide-trapping mechanism, but an inability to bind any of the halide to protein. In consequence, an equilibrium between thyroidal iodide and plasma iodide was reached and maintained. Such an equilibrium presumably occurs even when the binding rate of the thyroid is normal (5). Subsequently, the patient was taken off iodide drugs and a fully normal 
TABLE II

Eleven patients whose thyroids took up $I^{131}$ initially but tended to release it during period of observation (Figure 2) *

\begin{tabular}{|c|c|c|c|c|c|c|c|}
\hline \multirow[b]{2}{*}{ Patient } & \multirow{2}{*}{$\begin{array}{l}\text { Age, } \\
\text { sex }\end{array}$} & \multirow[b]{2}{*}{ Diagnosis } & \multicolumn{2}{|c|}{$\begin{array}{l}\text { Apparent } \\
\text { thyroidal clear- } \\
\text { ance of I131 at: }\end{array}$} & \multirow[b]{2}{*}{ BMR } & \multirow{2}{*}{$\underset{\text { PBI }}{\text { Serum }}$} & \multirow[b]{2}{*}{ Drugs } \\
\hline & & & $5 \min$ & $30 \mathrm{~min}$ & & & \\
\hline & & & \multicolumn{2}{|c|}{$m l / \min$} & $\%$ & $\mu \mathrm{g} / 100 \mathrm{ml}$ & \\
\hline 1 & 24 & $\begin{array}{c}\text { Hashimoto's } \\
\text { diseaset }\end{array}$ & $\begin{array}{l}47 \\
64\end{array}$ & $\begin{array}{l}16 \\
13\end{array}$ & -23 & 1.7 & $\begin{array}{l}\text { Before TSH } \\
\text { After TSH }\end{array}$ \\
\hline 2 & 33 & $\begin{array}{c}\text { Hashimoto's } \\
\text { diseaset }\end{array}$ & 33 & 18 & 0 & 4.6 & \\
\hline 3 & 31 & $\begin{array}{c}\text { Hashimoto's } \\
\text { diseaset }\end{array}$ & 85 & 49 & +5 & & \\
\hline 4 & $\begin{array}{l}49 \\
\mathrm{~F}\end{array}$ & $\begin{array}{l}\text { Probable } \\
\text { Hashimoto's } \\
\text { disease }\end{array}$ & 8 & 3 & +6 & 5.1 & \\
\hline 5 & $\frac{33}{F}$ & $\begin{array}{l}\text { Iodide } \\
\text { goitert }\end{array}$ & 149 & 74 & -11 & & Iodides $\ddagger$ \\
\hline 6 & $\begin{array}{l}13 \\
M\end{array}$ & $\begin{array}{l}\text { Goitrous } \\
\text { cretinism }\end{array}$ & 190 & 55 & & 2.5 & \\
\hline 7 & $\begin{array}{l}44 \\
F\end{array}$ & $\begin{array}{l}\text { Mild Graves' } \\
\text { disease }\end{array}$ & 93 & 25 & -3 & 3.9 & PTU§ \\
\hline 8 & $\begin{array}{l}58 \\
M\end{array}$ & Tension state & 17 & 4 & +6 & 5.0 & Tapazole\| \\
\hline 9 & $\begin{array}{l}39 \\
\text { M }\end{array}$ & $\begin{array}{l}\text { Osteoporosis; } \\
\text { hypogonadism }\end{array}$ & 21 & 4 & -14 & 2.5 & $\begin{array}{l}\text { PTUף } \\
\text { TSH }\end{array}$ \\
\hline 10 & $\begin{array}{l}66 \\
F\end{array}$ & $\begin{array}{l}\text { Previous I }{ }^{131} \\
\text { therapy, for } \\
\text { Graves' } \\
\text { diseaset }\end{array}$ & 13 & 5 & & & \\
\hline 11 & $\begin{array}{l}47 \\
F\end{array}$ & $\begin{array}{l}\text { Smooth, diffuse } \\
\text { goiter of uncer- } \\
\text { tain type } \dagger\end{array}$ & 71 & 22 & +18 & 8.7 & \\
\hline
\end{tabular}

*Abbreviations: $\mathrm{BMR}=$ basal metabolic rate; $\mathrm{PBI}=$ protein-bound iodine; $\mathrm{PTU}=$ propylthiouracil; $\mathrm{TSH}=$ thyroid-stimulating hormone.

$\dagger$ Tissue obtained at operation.

$¥$ For asthma.

$\$$ Received $200 \mathrm{mg} 3$ times a day for about a year.

Received $10 \mathrm{mg} 3$ times a day for 3 weeks.

Tी Received $100 \mathrm{mg} 3$ times a day for 8 days; received also bovine thyrotropin, 5 units daily, for 5 days before test.

function returned to the thyroid gland, including disappearance of the reversing uptake curve.

In the extensive literature on the effect of propylthiouracil, it is agreed that this drug primarily blocks protein binding of thyroidal iodine (6). A reversing uptake curve might, therefore, be expected to occur in patients receiving this drug. Ingbar (7) has proposed an explanation for the rarity of the phenomenon on the basis of the exorbitant doses required to halt the thyroidal binding rate effectively, especially in Graves' disease. He has, however, observed the reversing pattern in patients, as have Taurog, Chaikoff and Feller (8) in animals. Three of our patients were receiving propylthiouracil or methimazole.

Gardner, Hayles, Woolner and Owen (9), in a study of goitrous cretins, found that those patients incapable of converting thyroidal iodine to the protein-bound form were characterized by a reversing uptake curve. The release rate from the thyroid and the renal excretion rate of $\mathrm{I}^{131}$ were the same. Our patient with goitrous cretinism would seem to fit into this category.

By analogy with the various types of patients described above (goitrous, cretins, iodide goiter, propylthiouracil goiter), the same defect characterized the patient (Table II) who had had $\mathrm{I}^{131}$ therapy for hyperthyroidism, the four patients with Hashimoto's disease and the one with an undiagnosed goiter.

From Ingbar's data it is difficult to explain the findings in Hashimoto's disease; he estimated that the thyroidal binding rate had to be inhibited 90 per cent to obtain a "negative slope accumulation curve" (7). The level of hormonal iodine, i.e., butanol-extractable iodine and butanol-insoluble 
iodine (10) in the plasma of these patients often totals a normal value for protein-bound iodine (for example, Patients 2 and 4), suggesting a binding rate considerably greater than 10 per cent of normal. Although our experience with the Berson test in Hashimoto's disease is limited to these four patients, the unanimity of the finding of a reversing uptake curve suggests a new diagnostic clue.

The eleventh patient is difficult to classify, because we are not certain what type of goiter she had. She was 47 years old, with mitral stenosis and insufficiency, and was found to have a small, diffuse, non-nodular goiter. She was euthyroid clinically. The basal metabolic rate was plus 18 per cent. The protein-bound iodine was increased $\left(8.7 \mu \mathrm{g}\right.$ per $100 \mathrm{ml}$ ) but the uptake of $\mathrm{I}^{131}$ was not commensurate ( 13 per cent in one-half hour and 6 per cent in six hours, with only about 1 per cent remaining after 24 hours). No explanation for this discrepancy between protein-bound iodine and $\mathrm{I}^{131}$ uptake was found. No history of ingestion of interfering medication could be obtained. Needle biopsy of the thyroid showed mi- crofollicles and macrofollicles, but no thyroiditis or parenchymatous hypertrophy.

\section{SUMMARY AND CONCLUSIONS}

One hundred tracings of thyroid uptake were analyzed at intervals of $5,7.5,10,15,20$ and 25 minutes after extrathyroidal equilibration of intravenously administered $\mathrm{I}^{131}$, to establish constants for calculations of thyroidal clearance of plasma $I^{131}$ by the method of Berson and colleagues.

In the Berson calculation, a constant of 200 for the plasma $\mathrm{I}^{131}$ /body weight relationship was proposed for the usual 30 minute interval. Our calculated constants for shorter intervals were: $137.3 \pm 23.2(1 \mathrm{SD})$ at 5 minutes; $147.6 \pm 20.3$ at 7.5 minutes; $157.2 \pm 18.4$ at 10 minutes; $168.9 \pm 13.6$ at 15 minutes; $180.0 \pm 9.6$ at 20 minutes; and $191.1 \pm 6.9$ at 25 minutes. For clinical purposes the accuracy is sufficient at 20 minutes, so that we recommend shortening the test on a routine basis to 20 minutes, since the test is most useful in those patients least able to lie quietly, that is, those with Graves' disease.

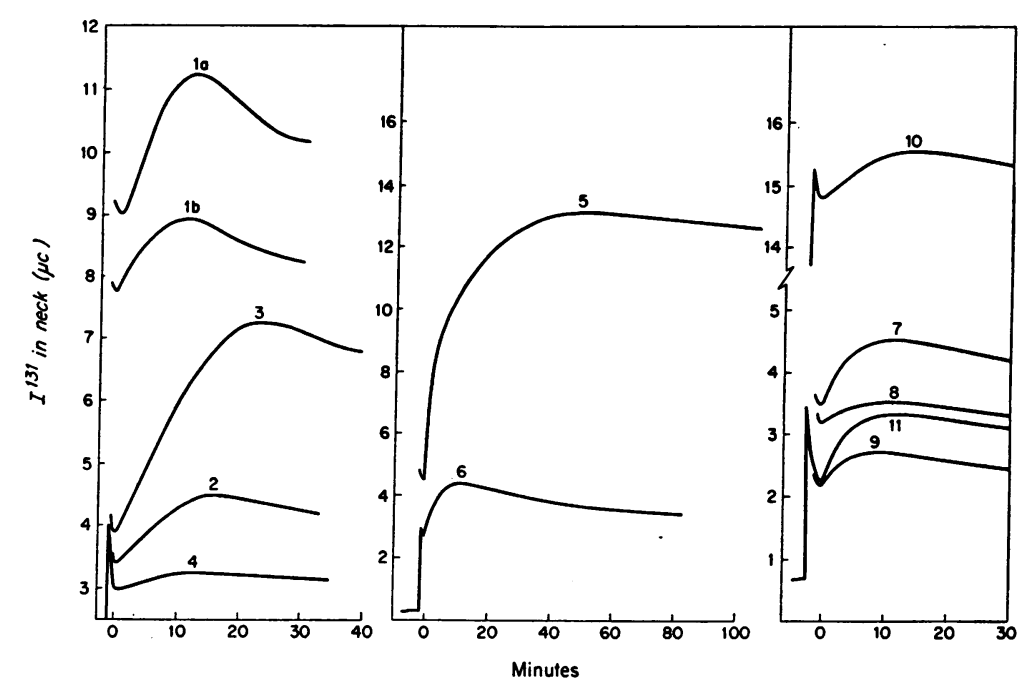

Fig. 2. Thyroidal uptake of $I^{131}$ in 11 patients who concentrated $I^{131}$ IN THEIR THYROIDS INITIALLY BUT SUBSEQUENTLY RELEASED PART OF IT (TABLE II). Uptake is recorded in microcuries of $\mathrm{I}^{131}$. The abscissa is time in minutes after equilibration of the $\mathrm{I}^{131}$ in the neck, that is, before actual thyroidal uptake has begun. The test was performed twice on $\mathrm{Pa}$ tient 1: 1a, before giving thyroid-stimulating hormone, and 1b, 24 hours after intramuscular injection of 10 units of bovine thyroid-stimulating hormone. Doses of $\mathrm{I}^{131}$ given Patient $1 \mathrm{a}$ and $1 \mathrm{~b}$ were 50.0 and $25.0 \mu \mathrm{c}$ respectively. Patients 2 through 11 received $23.8,23.5,50.5,52.0,14.7,23.8,22.3$, $50.4,51.5$, and $22.4 \mu \mathrm{c}$., respectively. 
With short-time constants available, the Berson clearance test may be abbreviated as needed for the convenience of the patient, or as required if the equipment should fail before the standard test is concluded, or as needed for evaluation of the rare patient who traps $\mathrm{I}^{131}$ but releases it promptly, presumably still in its inorganic form.

Eleven patients, from among 1,250 studied, exhibited the phenomenon of normal or accelerated thyroidal uptake of $\mathrm{I}^{131}$ followed, within the half hour of the Berson test, by reversal of the uptake curve. One patient was a goitrous cretin, one had an iodide goiter, three were receiving propylthiouracil or methimazole (Tapazole), and one had been treated with a therapeutic dose of $\mathrm{I}^{131}$. In these six patients, apparently complete block in thyroidal protein-binding of iodine existed; the loss of thyroidal radioiodide reflected the equilibrium between thyroidal and plasma iodide, an equilibrium dominated by the renal excretion of iodide.

The remaining five patients, four with Hashimoto's disease and one with a goiter of undiagnosed type, also exhibited a reversal of $\mathrm{I}^{131}$ uptake during the Berson test. Here the explanation is less clear; serum values for protein-bound iodine do not warrant the assumption of a prominent defect of protein-binding of iodine in the thyroid.

\section{REFERENCES}

1. Berson, S. A., Yalow, R. S., Sorrentino, J., and Roswit, B. The determination of thyroidal and renal plasma $\mathrm{I}^{131}$ clearance rates as a routine diagnostic test of thyroid dysfunction. J. clin. Invest. 1952, 31, 141.

2. Owen, C. A., Jr., McConahey, W. M., Keating, F. R., Jr., and Orvis, A. L. Investigation of diseases of the thyroid gland by means of radioactive iodine. Fed. Proc. 1955, 14, 723.

3. McConahey, W. M., Owen; C. A., Jr., and Keating, F. R., Jr. A clinical appraisal of radioiodine test of thyroid function. J. clin. Endocr. 1956, 16, 724.

4. Paris, J., McConahey, W. M., Owen, C. A., Jr., Woolner, L. B., and Bahn, R. C. Iodide goiter. J. clin. Endocr. 1960, 20, 57.

5. Nadler, N. J., and Leblond, C. P. Rates of passage of iodine into and out of the thyroid gland of the rat under various conditions of dietary iodine intake and body weight. Endocrinology 1958, 62, 768.

6. Astwood, E. B., and Bissell, A. Effect of thiouracil on the iodine content of the thyroid gland. Endocrinology 1944, 34, 282.

7. Ingbar, S. H. The influence of single doses of propylthiouracil on the kinetics of iodine accumulation by the thyroid glands of normal and hyperthyroid subjects. J. clin. Endocr. 1955, 15, 331.

8. Taurog, A., Chaikoff, I. L., and Feller, D. D. Mechanism of iodine concentration by thyroid gland; its non-organic iodine-binding capacity in normal and propylthiouracil-treated rat. J. biol. Chem. 1947, 171, 189.

9. Gardner, J. U., Hayles, A. B., Woolner, L. B., and Owen, C. A., Jr. Iodine metabolism in goitrous cretins. J. clin. Endocr. 1959, 19, 638.

10. Owen, C. A., Jr., and McConahey, W. M. An unusual iodinated protein of the serum in Hashimoto's thyroiditis. J. clin. Endocr. 1956, 16, 1570. 